\title{
Long-term persistence of Mediterranean pine forests in the Duero Basin (central Spain) during the Holocene: The case of Pinus pinaster Aiton
}

\author{
César Morales-Molino, ${ }^{1,2}$ José M Postigo-Mijarra,' Carlos Morla' and \\ Mercedes García-Antón²
}

\begin{abstract}
In the southern Duero Basin of central Spain, there are vast areas of aeolian sand sheets and dune fields. A comprehensive survey of the sand quarries in this area identified a number of palaeosols in sedimentary sequences. The identification and AMS radiocarbon dating of soil charcoal fragments collected in these palaeosols indicate the persistence of Pinus pinaster in this area throughout most of the Holocene. Although potential natural vegetation models have usually considered the Pinus pinaster forests in this inland area of artificial origin, soil charcoal analysis provides firm evidence of a natural origin. Our data fit perfectly with the pattern of Holocene vegetation development for inland areas of lberia, which are characterised by stability of pine forests throughout the Holocene. Finally, the growing body of palaeobotanical evidence from lberia (macrofossils and pollen) is contributing to improve our knowledge of $P$. pinaster ecology, showing that this species has been present in most lberian regions during the Holocene, where it has inhabited areas characterised by a very diverse set of climatic and soil conditions.
\end{abstract}

Keywords

historical biogeography, Iberian Peninsula, macrofossils, palaeoecology, soil charcoal analysis, vegetation history

\section{Introduction}

The Iberian Peninsula is an area of great biogeographical importance and interest during the late Quaternary in the western Palaearctic context (Carrión and Leroy, 2010). This importance is primarily because of the number and significance of glacial refugia for temperate and Mediterranean flora in this region during the Late Pleistocene (González-Sampériz et al., 2010) and because the Holocene patterns of vegetation development are different here than in the rest of Europe (Carrión et al., 2010). Within this general geographical setting, Iberian inland areas, such as the Duero Basin, are of special interest. Palaeoecological information is still scarce throughout this area (Carrión et al., 2010; Postigo-Mijarra et al., 2010), despite the recent publication of several pollen sequences (Franco-Múgica et al., 2001, 2005; García-Antón et al., 2011) and anthracological studies carried out in archaeological settlements (Hernández et al., 2011; López-García et al., 2003). These palaeoecological records indicate a truly unique Holocene vegetation history characterised both by the millennial persistence of pinewoods as the dominant vegetation type and by the relatively late onset of human impacts on the natural environment.

Major features of the southern edge of the Duero sedimentary basin are large areas covered with stabilised dune fields and aeolian sand sheets that are currently forested with pine woods dominated by Pinus pinaster Aiton (maritime pine) and Pinus pinea L. (Calonge, 1998; Ruiz de la Torre, 1996). These pine forests have been commonly considered as afforestations with a clear anthropogenic origin, probably for the purpose of stabilising the dunes (Navarro and Valle, 1987). Therefore, the most recent publications addressing phytosociology on the Iberian Peninsula consider neither $P$. pinaster nor $P$. pinea to play a role in well-developed forests (Peinado et al., 2008; Rivas Martínez et al., 2001, 2002). However, another group of researchers has long claimed that these pines are autochthonous in this area (Font Quer, 1954). They have also shown the importance of pine forests as the main natural vegetation type on these aeolian sediments (Calonge, 1987; Gil, 1991) based on both historical sources and ecological evidence. Improving our knowledge about the origin of these forest stands is especially relevant at present, as European environmental policies promote the conservation and restoration of natural forest communities. Palaeobotanical research can provide crucial information on this subject.

However, pollen analysis cannot always distinguish which particular species of pine produced a pollen signal. Analysis of plant macrofossils, such as charcoal fragments, pine needles or pinecones, allows specification of the group of pines, or even the particular species, that was/were present near the deposition site (e.g. Figueiral, 1995; Garé́a Álvarez et al., 2009). Thus, investigation of charcoal fragments collected at archaeological

'Universidad Politécnica de Madrid, Spain
${ }^{2}$ Universidad Autónoma de Madrid, Spain

Corresponding author:

César Morales del Molino, U.D. de Botánica, E.T.S.I. de Montes, Universidad Politécnica de Madrid, Ciudad Universitaria s/n 28040 Madrid, Spain.

Email: cesar.morales@upm.es 


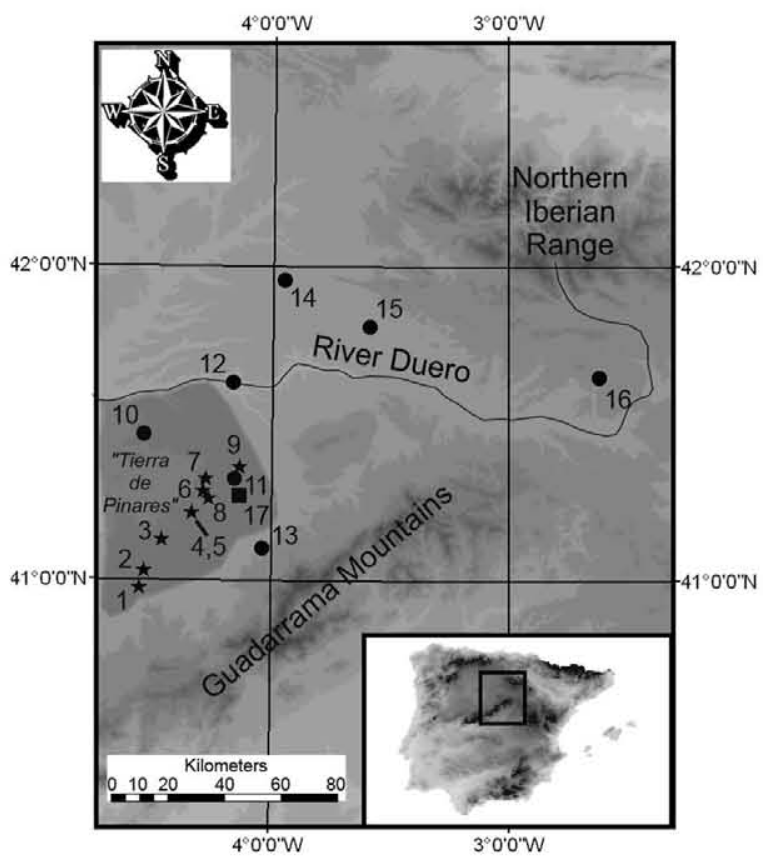

Figure I. Location of the study sites and other palaeoecological sites in the Duero Basin (central Spain). Study sites: I: Martín Muñoz de las Posadas (MART); 2: Juarros de Voltoya (JUA-VOLT); 3: Nava de la Asunción (NAV-AS); 4 and 5: Mudrián I and 2 (MUD I and MUD 2); 6: Gomezserracín (GOM); 7: Sanchonuño (SANCH); 8: Pinarejos (PIN). Other palaeoecological sites discussed in the text: 9: Hontalbilla (HON) (Alcalde et al., 2004); 10: Camporredondo (García-Antón et al., 201 I); II: El Carrizal Lake (Franco-Múgica et al., 2005); I2: Pintia (Hernández et al., 201 I); 13: Cueva de la Vaquera (López-García et al., 2003); I 4: Espinosa de Cerrato (Franco Múgica et al., 2001); 15: Tubilla del Lago (García-Amorena et al., 201 I); 16: Quintana Redonda (García Antón et al., 1995). 17: River Cega: Pinus sylvestris and $P$. nigra relict stands in the lowlands of the Duero Basin. The shaded area labelled as 'Tierra de Pinares' shows the approximate location of this region

sites can reveal the presence of woody taxa growing in relative proximity to human settlements. Soil charcoal analysis adds high spatial resolution to the taxonomical precision of anthracological analysis and, thus, allows the reconstruction of vegetation history at a local scale (Carcaillet, 2007; Carcaillet and Thinon, 1996). Moreover, the proportions among taxa are not affected by human bias when analysing soil charcoal assemblages, allowing to faithfully reflect the composition of the burnt vegetation. This technique has most commonly been employed to precisely reconstruct Holocene treeline oscillations (Carcaillet, 1998; Carnelli et al., 2004; Talon, 2010) and to find out whether the origin of certain steppic communities is natural or anthropogenic (Dutoit et al., 2009; Henry et al., 2010), thus completing results obtained from pollen sequences.

Preliminary analysis of charcoal specimens from the soils of the southern Duero Basin showed the presence of the maritime pine in this area c. $1500 \mathrm{cal}$. yr BP (Alcalde et al., 2004). Similarly, Hernández et al. (2011) found an important number of charcoal fragments of $P$. pinaster and $P$. pinea in an Iron Age city located in the central Duero Basin. These promising results led us to carry out a comprehensive study of the soil charcoal in an extensive area of the inner Duero Basin. Our main objectives were the following: (i) to obtain spatially precise vegetation reconstructions from these sandy environments for the Holocene, evaluating the long-term persistence of pine forests over extensive areas of the southern Duero Basin, (ii) to specify which pine species have been growing in this area, improving upon the taxonomical accuracy of the existing results from pollen studies, and (iii) to examine the significance of $P$. pinaster in the Holocene landscapes of the Iberian Peninsula.

\section{Study area}

At the southern edge of the Duero Basin (between the River Duero and the foothills of the Guadarrama Mountains), there is a region known as Tierra de Pinares (land covered with pine forests), where the main features are extensive areas of aeolian sand sheets and stabilised dune fields located at an altitude ranging from 700 to $900 \mathrm{~m}$ a.s.l. (Figure 1). These are the most extensive in the Iberian Peninsula and cover approximately $1800 \mathrm{~km}^{2}$ (GarcíaHidalgo et al., 2007). The most characteristic aeolian forms are sand sheets and simple and compound parabolic dunes. The sand sheets cover approximately $1500 \mathrm{~km}^{2}$, and their thickness ranges from a few centimetres to 4-5 $\mathrm{m}$ (Bernat and Pérez-González, 2008), whereas the dunes can reach heights of 50-60 m (Bateman and Díez-Herrero, 1999). Thermoluminescence dating indicates that the main periods of dune formation were c. 13.5-11.5 ka BP, during the cold and dry stages of the Younger Dryas, and c. $8 \mathrm{ka}$ BP, during the $8.2 \mathrm{ka}$ event (Bateman and Díez-Herrero, 1999; Bernat and Pérez-González, 2008). In addition, other periods of aeolian activity and dune formation have been recognised between 5 and $2 \mathrm{ka} \mathrm{BP}$ and during the 'Little Ice Age, between 0.5 and 0.2 ka BP (Bernat and Pérez-González, 2008).

The present climate in this area is continental Mediterranean, with a summer drought lasting for four months. The mean annual temperature ranges from 11 to $13^{\circ} \mathrm{C}$ and the average annual rainfall is between 400 and $550 \mathrm{~mm}$. Maritime pine forests are the dominant vegetation type in the study area, with mixed stands of $P$. pinaster and $P$. pinea in places where the winter frosts are less severe. The extent of these natural forests was increased greatly by afforestation during the last decades of the 19th century $\mathrm{AD}$ (Cortázar, 1891) and during the $\mathrm{AD} 1940$ s (ICONA, 1995) to foster resin and pine nut production and to stabilise the dunes.

\section{Materials and methods}

In the sand sheets and dune fields of Tierra de Pinares, there are a high number of quarries where sand is mined, providing vertical exposures where it is possible to recognise the stratigraphy of these aeolian forms, and consequently they have been widely used by geomorphologists to study the origin and evolution of the aeolian sand formations (Bateman and Díez-Herrero, 1999; Bernat and Pérez-González, 2008; García-Hidalgo et al., 2007). This has revealed the presence of palaeosols with a more or less developed organic layer (Bernat and Pérez-González, 2008; GarcíaHidalgo et al., 2007), where charred material was occasionally found (García-Hidalgo et al., 2007). We therefore inspected 26 exposed sedimentary profiles, where we examined the palaeosols and other organic layers for charred material (Figure 2). We then picked up with tweezers all the charcoal fragments we could distinguish in the palaeosols. Of these 26 profiles, only eight of them presented palaeosols with woody charcoal suitable for palaeobotanical analysis. The depths and exact locations of the 13 studied palaeosols are shown in Table 1.

From all the charcoal fragments collected at the study sites, we only analysed those 148 which were longer than $1 \mathrm{~mm}$. The charcoal fragments were manually fractured or cut with a scalpel along the three main anatomical sections of the wood (transverse, radial and tangential). The anatomical features necessary to identify the woody charcoal samples could be recognised in these sections. The charcoal sections were observed under an incident light microscope with differential interference contrast at $50 \times, 100 \times$, $200 \times$ and $400 \times$ magnifications. Taxonomical identification was achieved using atlases and keys of wood anatomy (Jacquiot, 1955; Schweingrüber, 1990; Vernet et al., 2001) and through comparison with the wood reference collection in the U.D. Botánica of the Forestry School at the Technical University of Madrid. In addition, we collected 15 cone scales whose identification was achieved through comparison with reference material 

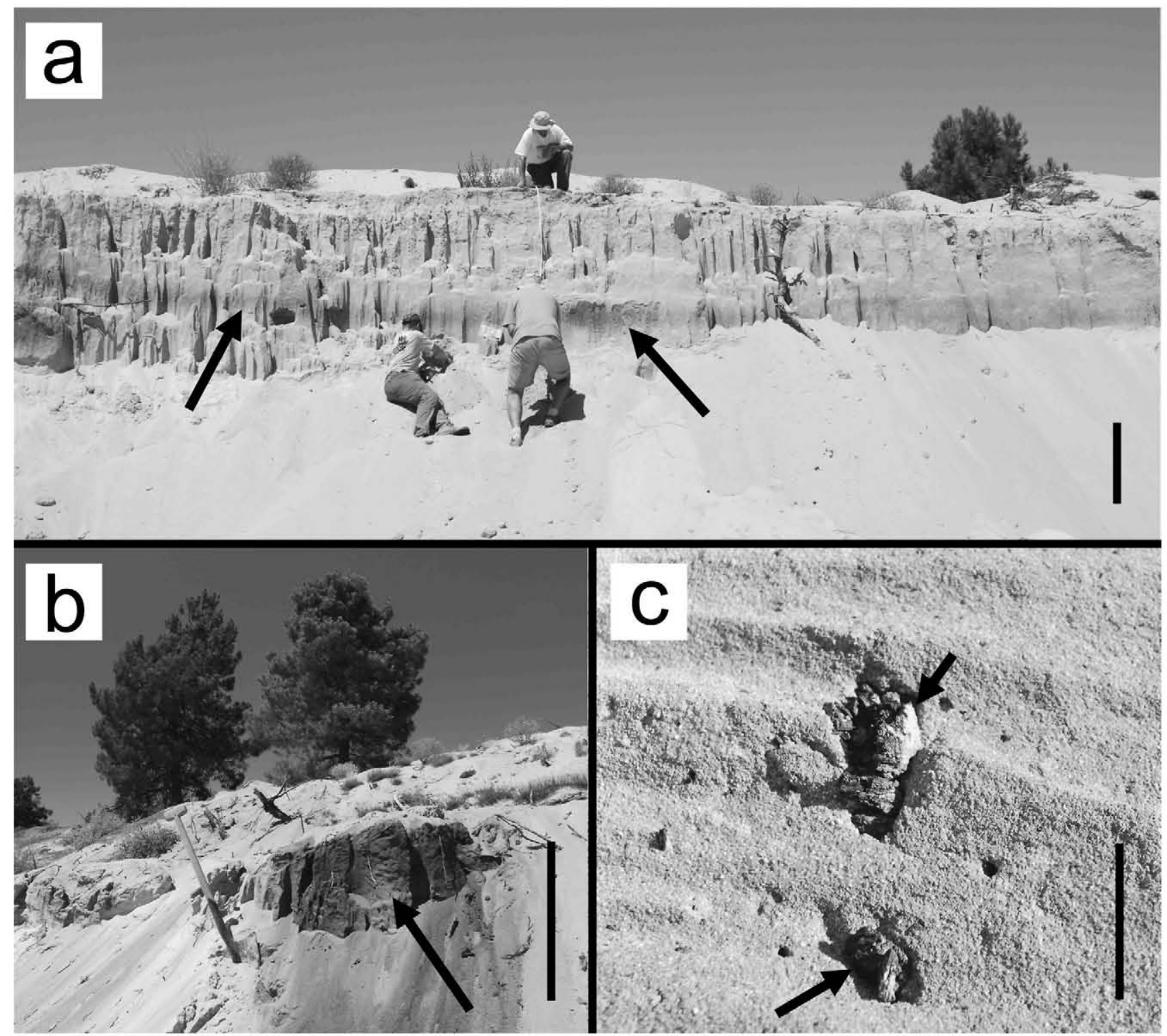

Figure 2. Sampling area where part of the charcoal fragments was collected, Pinarejos (Segovia): (a) Arrows point to one of the sampled palaeosols (darker layer). Scale bar: I m. (b) The arrow points to a soil charcoal outcrop belonging to a palaeosol. Scale bar: I m. (c) The arrows point to two charcoal fragments found in the palaeosol PIN C. Scale bar: I cm

deposited in the EMMA Herbarium (Forestry School, Technical University of Madrid).

Our preliminary analysis showed that most of the charcoal fragments belonged to Mediterranean pines. There are three species of Mediterranean pines on the Iberian Peninsula presenting wood characterised by cross-fields with oval pinoid pits (radial section): P. pinaster, P. pinea and P. halepensis Miller. In P. pinaster wood, the radial tracheid walls are commonly and conspicuously dentate, whereas those of $P$. pinea are usually smooth (Figueiral, 1995; Schweingrüber, 1990). P. halepensis wood has radial tracheid walls weakly dentate, with short teeth arranged in an irregular pattern (Jacquiot, 1955; Vernet et al., 2001). When the charcoal fragments were well preserved, we could usually identify them to the species level; otherwise, the fragments were characterised as belonging to the Pinus pinaster/pinea group, where $P$. halepensis would be included too.

Thirteen charcoal fragments from different palaeosols were radiocarbon-dated using AMS (one from each palaeosol, except for SANCH - site 7 in Figure 1 - where two samples were dated). The conventional radiocarbon ages were rounded to the nearest decade and then converted to calendar years using the CALIB 6.0.1 program (Stuiver and Reimer, 1993) and the calibration curve INTCAL09 (Reimer et al., 2009).

\section{Results}

The results of the identification of charcoal fragments are shown in Figure 3. All of the identified charcoal fragments belong to the genus Pinus, and most of them are P. pinaster type or P. pinaster/ pinea group (Figure 4). The radiocarbon dates (Table 1) of the charcoal fragments range between 5600 and $350{ }^{14} \mathrm{C}$ yr BP. The absence of taxa other than pine is remarkable, given the extensive area (approximately $375 \mathrm{~km}^{2}$ ) and the wide time span considered (Table 1; Figure 5a)

\section{Discussion}

\section{Taphonomical considerations on soil charcoal deposition in sandy environments}

In the sedimentary environment in which the palaeosols developed, the older sediment layers are below the more recent ones. This is supported by the radiocarbon dates obtained from different organic layers located at different depths of the same sedimentary profile (i.e. NAV-AS and PIN, see Table 1). In addition, two charcoal fragments (SANCH A1 and SANCH A2) from a single tilted palaeosol that were radiocarbon dated, yielded the same age (see Table 1), thus supporting the existence of this kind of stratification. 
Table I. Radiocarbon dates obtained from the macroscopic charcoal samples collected from different palaeosols in the Tierra de Pinares area (Segovia, central Spain). The numbers preceding the site name are those used in Figure I

\begin{tabular}{|c|c|c|c|c|c|c|}
\hline Site & Layer name & Depth $(\mathrm{cm})$ & Taxon & $\begin{array}{l}\text { Conventional age } \\
\left({ }^{14} \mathrm{C} \text { yr BP }\right)\end{array}$ & $\begin{array}{l}\text { Calibrated age } \\
\text { (cal. yr BP, } 2 \sigma)^{\mathrm{a}}\end{array}$ & Laboratory reference \\
\hline $\begin{array}{l}\text { I Martín Muñoz de las } \\
\text { Posadas } \\
40^{\circ} 58^{\prime} 35^{\prime \prime} \mathrm{N} \\
4^{\circ} 32^{\prime} 39^{\prime \prime} \mathrm{W} \\
870 \mathrm{~m} \text { a.s.l. }\end{array}$ & MART & 40 & Pinus pinaster & $2280 \pm 30$ & $2350-2160$ & CNA-768 \\
\hline $\begin{array}{l}2 \text { Juarros de Voltoya } \\
41^{\circ} \mathrm{I}^{\prime} 2 \mathrm{I}^{\prime \prime} \mathrm{N} \\
4^{\circ} 3 \mathrm{I}^{\prime} 48^{\prime \prime} \mathrm{W} \\
850 \mathrm{~m} \text { a.s.l. }\end{array}$ & JUA-VOLT & 50 & Pinus pinaster & $2640 \pm 40$ & $2850-2720$ & CNA-767 \\
\hline 3 Nava de la Asunción & NAV-ASA & 150 & Pinus pinaster & $2570 \pm 30$ & $2760-2510$ & CNA-77I \\
\hline $\begin{array}{l}41^{\circ} 7^{\prime} 34^{\prime \prime} \mathrm{N} \\
4^{\circ} 27^{\prime} 2 I^{\prime \prime} \mathrm{W} \\
820 \mathrm{~m} \text { a.s.l. }\end{array}$ & NAV-AS B & 250 & Pinus pinaster & $3650 \pm 40$ & $4090-3870$ & $\beta-26000 \mid$ \\
\hline $\begin{array}{l}4 \text { Mudrián } \\
41^{\circ} 13^{\prime} 8^{\prime \prime} \mathrm{N} \\
4^{\circ} 19^{\prime} 59^{\prime \prime} \mathrm{W} \\
830 \mathrm{~m} \text { a.s.l. }\end{array}$ & MUD I & 150 & Pinus pinaster & $650 \pm 40$ & $670-550$ & $\beta-260004$ \\
\hline $\begin{array}{l}5 \text { Mudrián } \\
41^{\circ} 12^{\prime} 56^{\prime \prime} \mathrm{N} \\
4^{\circ} 19^{\prime} 44^{\prime \prime} \mathrm{W} \\
830 \mathrm{~m} \text { a.s.l. }\end{array}$ & MUD 2 & 100 & Pinus pinaster & $2150 \pm 30$ & $2300-2010$ & CNA-772 \\
\hline $\begin{array}{l}6 \text { Gomezserracín } \\
41^{\circ} 17^{\prime} 20^{\prime \prime} \mathrm{N} \\
4^{\circ} 17^{\prime} 25^{\prime \prime} \mathrm{W} \\
820 \mathrm{~m} \text { a.s.l. }\end{array}$ & GOM & 200 & Pinus gr. pinaster/pinea & $370 \pm 30$ & $500-320$ & $\beta-260002$ \\
\hline $\begin{array}{l}7 \text { Sanchonuño } \\
41^{\circ} 18^{\prime} 38^{\prime \prime} \mathrm{N} \\
4^{\circ} 17^{\prime} 2 I^{\prime \prime} \mathrm{W}\end{array}$ & SANCHAI & 30 & Pinus gr. pinaster/pinea & $1160 \pm 30$ & $1170-980$ & CNA-774 \\
\hline $820 \mathrm{~m}$ a.s.l. & SANCHA2 & 50 & Pinus pinaster & $1150 \pm 40$ & $1170-960$ & CNA-773 \\
\hline 8 Pinarejos & PINA & 100 & Pinus pinaster ${ }^{b}$ & $350 \pm 40$ & $500-300$ & $\beta-260003$ \\
\hline $41^{\circ} 16^{\prime} 11^{\prime \prime} \mathrm{N}$ & PIN B & 170 & Pinus pinaster & $4360 \pm 40$ & $5040-4850$ & CNA-770 \\
\hline $\begin{array}{l}4^{\circ} 16^{\prime} 26^{\prime \prime} \mathrm{W} \\
830 \mathrm{~m} \text { a.s.I. }\end{array}$ & PIN C & 240 & Pinus gr. pinaster/pinea & $5600 \pm 40$ & $6450-6300$ & CNA-769 \\
\hline $\begin{array}{l}9 \text { Hontalbillac }^{c} \\
41^{\circ} 2 I^{\prime} 22^{\prime \prime} \mathrm{N} \\
4^{\circ} 8^{\prime} 6^{\prime \prime} \mathrm{W} \\
850 \mathrm{~m} \text { a.s.l. }\end{array}$ & $\mathrm{HON}$ & 40 & Pinus pinaster & $1590 \pm 100$ & $1700-1290$ & $\beta-127246$ \\
\hline
\end{tabular}

a Calibrated ages were obtained using CALIB 6.0 software (Stuiver and Reimer, 1993) with the calibration data set INTCAL09 (Reimer et al., 2009 ).

${ }^{b}$ Cone scales.

'These results were previously published in Alcalde et al. (2004).

This finding is of great importance when interpreting the soil charcoal record, as the charcoal fragments found in a charcoal layer seem to be contemporary. This is not the case in other environments where there is a lack of stratification with mixing of charcoal fragments of very different ages. This occurs for example in alpine and subalpine soils through soil bioturbation, tree uprooting and freeze-thaw processes (Carcaillet, 2001, 2007; Talon, 2010)

\section{Long-term stability of Pinus pinaster forests in the Duero Basin}

In this paper, we present the results of a comprehensive soil charcoal study showing that the maritime pine has been present over extensive areas of the southern Duero Basin along most of the Holocene (see Figures 1, 3). The genus Pinus was the only taxon identified. Because the analysed charcoal fragments were always longer than $1 \mathrm{~mm}$, it is likely that their origin was very close to the deposition site (Clark et al., 1998; Lynch et al., 2004). The exclusively local origin, together with the homogeneous environment and the limiting conditions for vegetation development that are characteristic of sandy soils, may explain the low taxonomic diversity. This contrasts markedly with the anthracological record for Pintia (Figure 1), a Vaccaean (Iron Age) settlement where $P$. pinaster and the $P$. pinaster/pinea group were also the dominant taxa (Hernández et al., 2011) but the taxonomic richness is strikingly higher, probably because of environmental diversity (Hernández et al., 2011) and/or to anthropogenic bias (Rubiales et al., 2011).

Dominance of pine forests in this inland Iberian area throughout the Holocene has been previously shown in pollen sequences from Espinosa de Cerrato (Franco-Múgica et al., 2001), El Carrizal (Franco-Múgica et al., 2005; Figure 5b) and Camporredondo (García-Antón et al., 2011), where Pinus pollen was dominant for the last 10,000 years. On the basis of these sequences, it has been suggested that $P$. pinaster has been the main pine species since $c$. $8500-9000$ cal. yr BP, following an expansion associated with the Holocene climatic amelioration (García-Antón et al., 2011). The soil charcoal record for Tierra de Pinares shows that the maritime pine has been the most widespread species on the dune fields and aeolian sand sheets of this region since at least c. $6500 \mathrm{cal}$. yr 


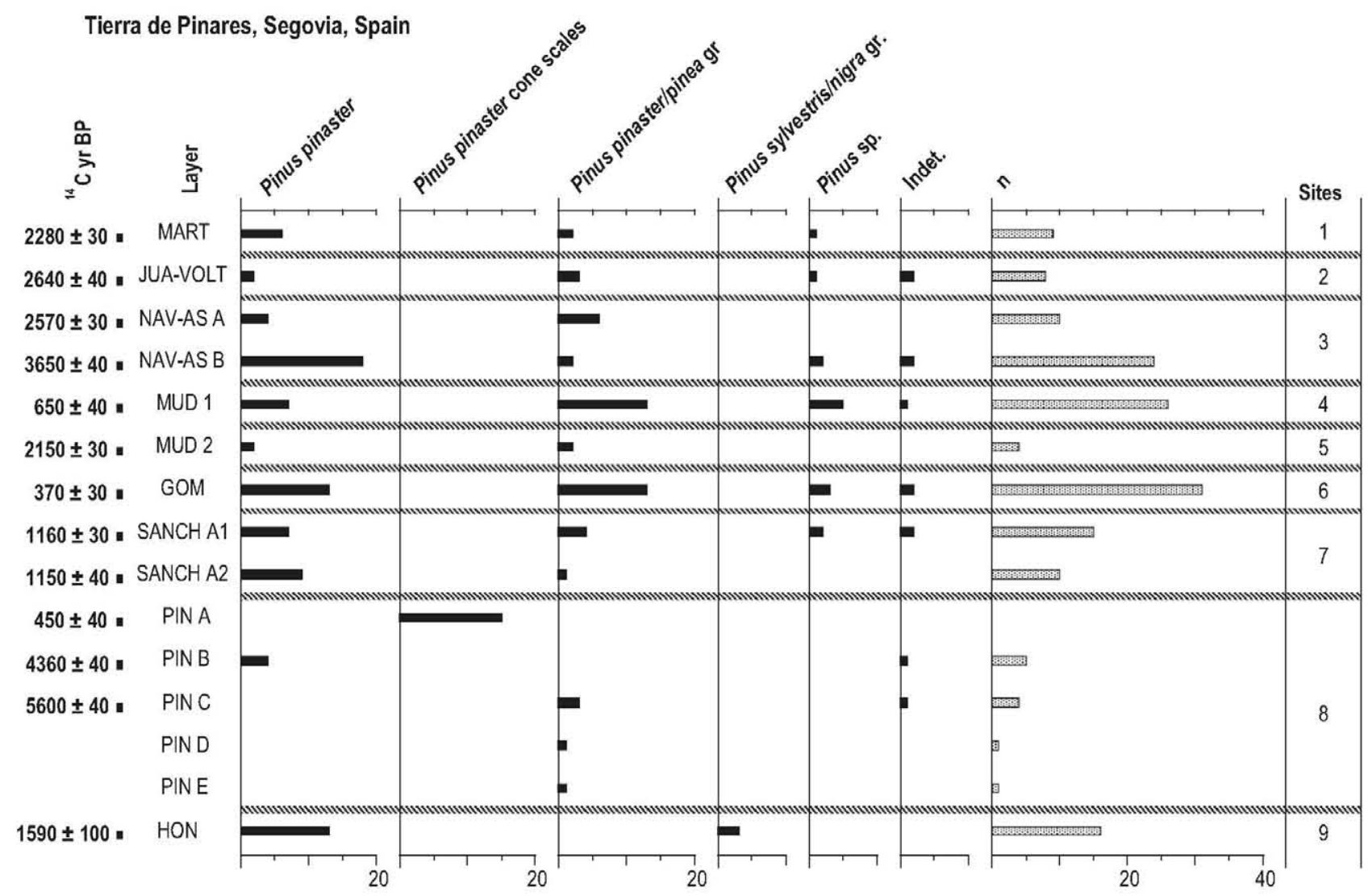

Figure 3. Macrofossil diagram showing the results of the analyses carried out on soil charcoal fragments from palaeosols of the Tierra de Pinares area. The palaeosols ('layer') are designated according to Table I. The site numbers are the same as used in Figure I. Results from Hontalbilla (HON) were already published by Alcalde et al. (2004)
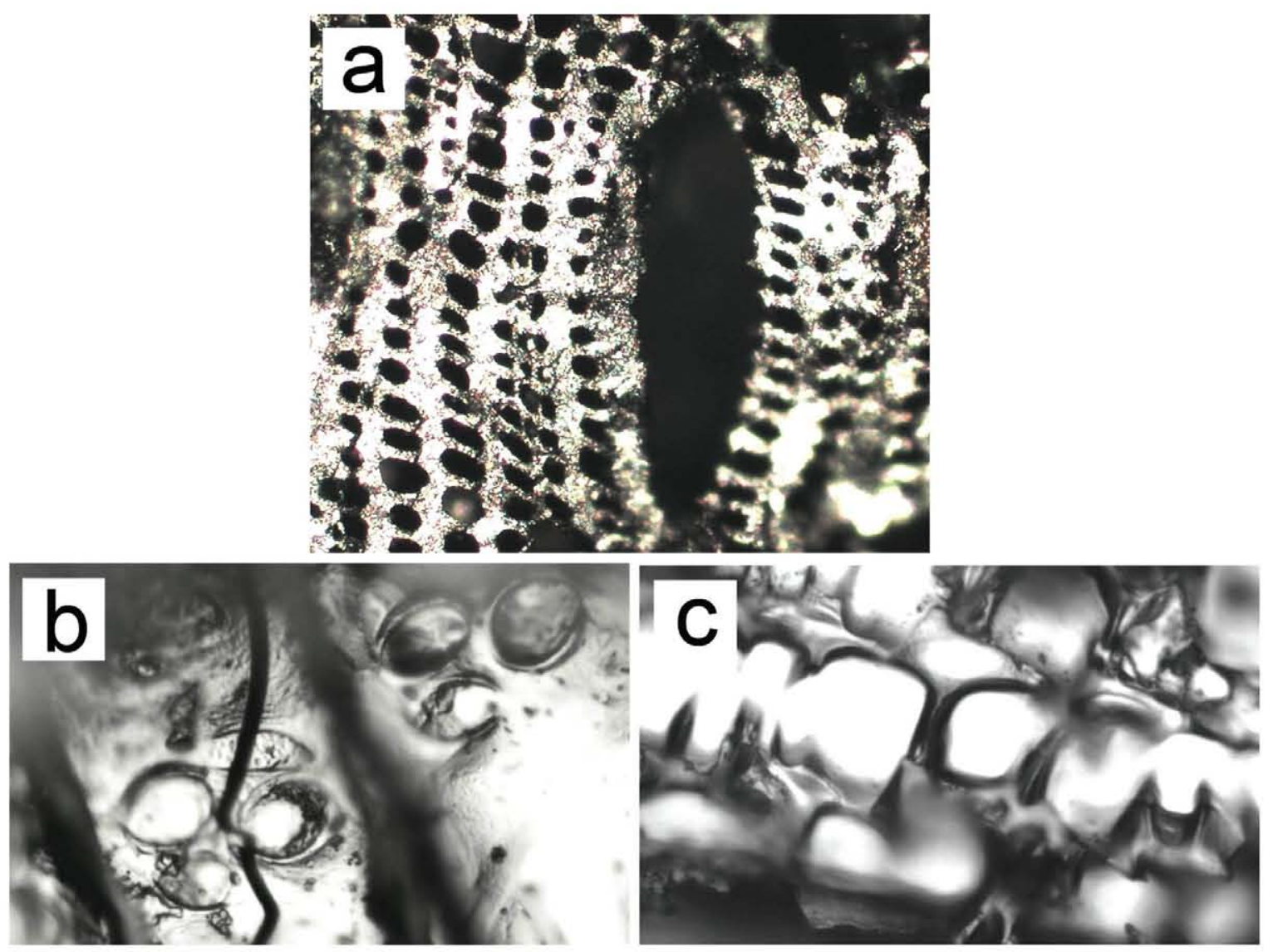

Figure 4. Photographs showing some of the most characteristic microscopic features of the wood anatomy of $P$. pinaster. (a) Transverse section. Axial tissue without vessels. Large resin canal with thin-walled epithelial cells. (b) Radial section. Cross-fields with 3-4 pinoid pits. (c) Radial section. Radial tracheids conspicuously dentate 
(a)

\section{Tierra de Pinares}

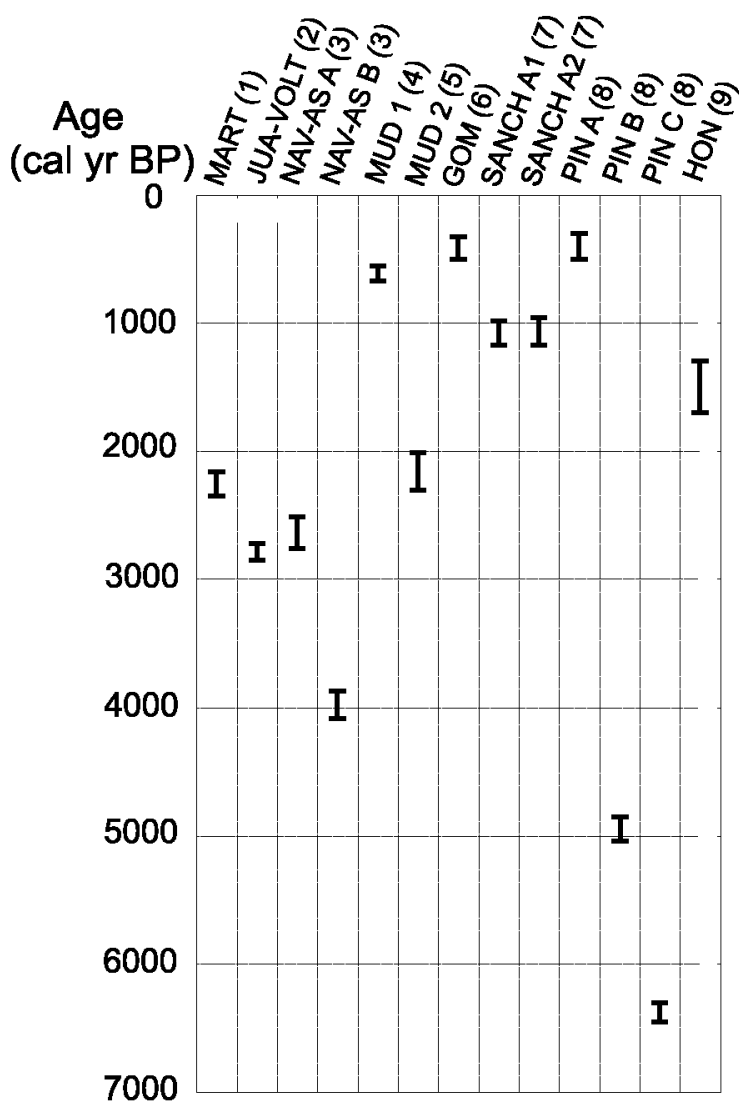

(b)

El Carrizal Lake

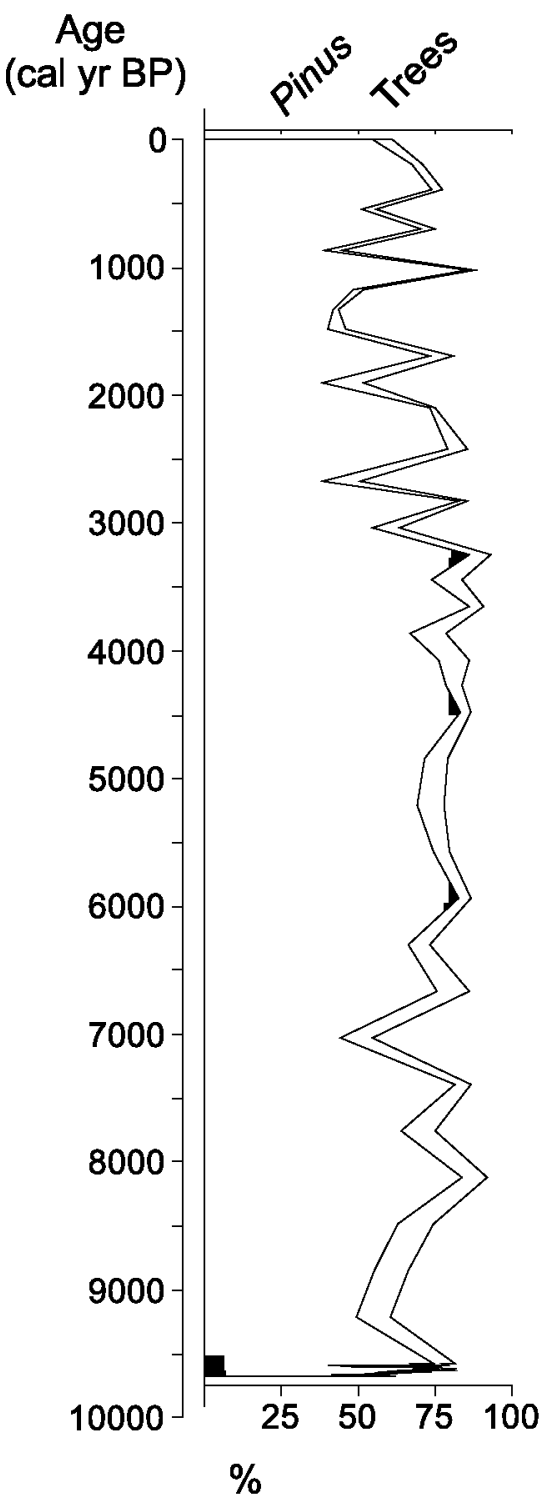

Figure 5. Palaeobotanical evidence supporting the long-term persistence and dominance of pines at the southern edge of the Duero Basin. (a) AMS radiocarbon dates of soil charcoal from the Tierra de Pinares area. The numbers in brackets following the site names are those of the map in Figure I.The ages shown are the $95.4 \%$ probability intervals of the calibrated radiocarbon ages obtained using the CALIB 6.0 program (Stuiver and Reimer, 1993) and the INTCAL09 curve (Reimer et al., 2009). (b) Pinus and tree pollen curves from the El Carrizal sequence (Franco-Múgica et al., 2005). The proportion of pine pollen is high in comparison with the total amount of tree pollen

BP (Figure 5a), persisting until today. This new palaeobotanical evidence joins a small set of $P$. pinaster charcoal fragments from Hontalbilla (Figure 1) with an age $1700-1290$ cal. yr BP (Alcalde et al., 2004). Data from archaeological sites also support the Holocene importance of the maritime pine in this geographical framework: $P$. pinaster charcoal fragments with an age of $7400-5300$ cal. yr BP were recovered from Neolithic levels of the Cueva de la Vaquera (Figure 1) (López-García et al., 2003), whereas in the Iron Age (2800-2300 cal. yr BP) anthracological assemblage of Pintia (Figure 1), this pine species clearly represents the most common taxon (Hernández et a1., 2011). Finally, the available historical record demonstrates considerable economic and ecological importance of the pine forests in this region since at least the Middle Ages (Calonge, 2003; Gil, 1991, 2008). The long-term persistence of these pine forests may be explained by the unsuitability of the sandy soils for crop cultivation and animal husbandry. Moreover, broadleaved trees are less competitive than conifers in continental Mediterranean areas, such as the eastern part of the Duero Basin (Costa et al., 1997).

Phylogeographical studies have also supported an ancient presence of the maritime pine in the Duero Basin. The gene pool of $P$. pinaster populations of the Duero Basin is different from that of $P$. pinaster stands from other relatively close areas, which could be due to long-term isolation during the Pleistocene (de Lucas et al., 2009). Unfortunately, it has not yet been possible to test this hypothesis, as there is no fossil evidence of $P$. pinaster during the Late Pleistocene in the Tierra de Pinares. The absence of Late Pleistocene sites is probably associated with arid climates.

Pinus sylvestris L. and Pinus nigra Arnold have also been present in the pine forests of the Duero Basin during the Holocene. Dominance of these species during the early Holocene has been suggested based on regional pollen sequences. From the early- to 


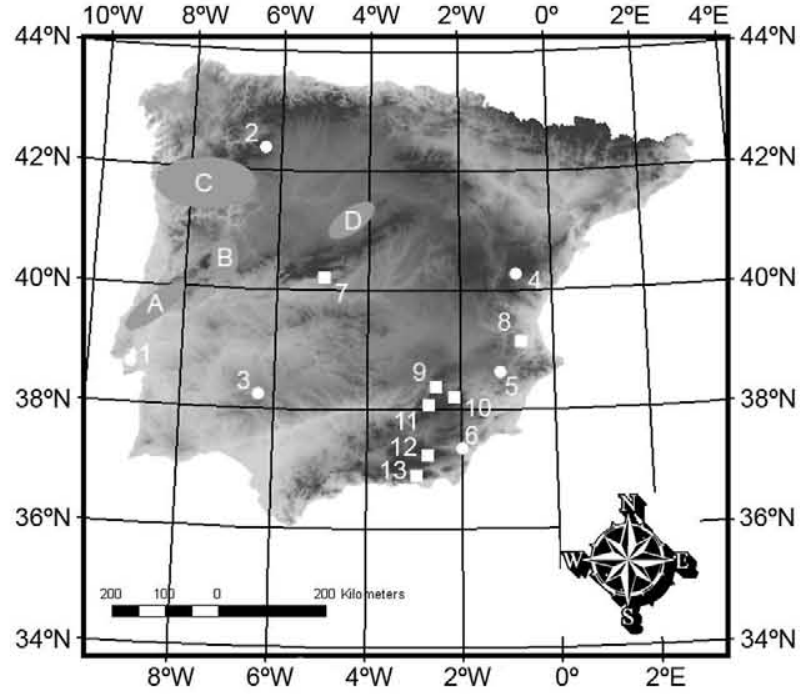

Figure 6. Map showing the main palaeobotanical sites where P. pinaster has been identified in lberia during the Holocene. Macrofossil sites: A and B: Central Portugal, several sites (Figueiral, 1995); C: Northern Portugal, several sites (Figueiral, 1995; Figueira and Bettencourt, 2004;Tereso, 2009); D:Tierra de Pinares, several sites (this study); I: Barreiros (García-Amorena et al., 2007); 2: Teleno (Domergue and Herail, 1978); 3: Castillejos II (Rubiales et al., 2009); 4: Mora de Rubielos (Richter and Eckstein, 1986); 5:Yecla (Alcalde et al., 2004); 6: Santa Bárbara (Rodríguez-Ariza, 2000). Pollen sites: 7: Lanzahíta (López-Sáez et al., 2010); 8: Navarrés (Carrión and van Geel, 1999); 9: Siles (Carrión, 2002); 10: El Sabinar (Carrión et al., 2004); I I: Cañada de la Cruz (Carrión et al., 200I); 12: Sierra de Baza (Carrión et al., 2007); I 3: Sierra de Gádor (Carrión et al., 2003)

mid-Holocene transition onwards, these cryophilous pines would have been replaced by the maritime pine, a more mesic pine (García-Antón et al., 2011). Furthermore, the macrofossil record provides evidence of the presence of $P$. sylvestris and $P$. nigra at several low-altitude sites on the eastern edge of the Duero Basin, during both the early Holocene (García Antón et al., 1995) and the mid to late Holocene (García-Amorena et al., 2011; Roig et al., 1997). In our study area, the $P$. sylvestris/nigra type dominates the anthracological assemblage of the Cueva de la Vaquera (mid Holocene; López-García et al., 2003), it is also present in Hontalbilla (late Holocene; Alcalde et al., 2004) and is well represented in Pintia, an Iron Age settlement (late Holocene; Hernández et al., 2011). Our soil charcoal data set lacks the Pinus sylvestris/nigra type, which is a remarkable difference compared with those sites discussed previously. This striking feature of the Tierra de Pinares soil charcoal record could be caused by the fact that both the Cueva de la Vaquera and Pintia are sites where human inhabitants collected the wood over a potentially wide area. This area could have included a variety of habitats with different soil properties and topographic features, where there would have been sites where humidity and/or soil moisture was higher (e.g. north-facing slopes, riparian corridors, alluvial plains), allowing the survival of this/these pine species. Thus, the relict stands of $P$. sylvestris and $P$. nigra that currently remain along the River Cega are located at the bottom of the valley or on slopes where groundwater discharge occurs (Guerra et al., 2006). In contrast, the soil charcoal data presented in this report are of a purely local origin and were collected in a completely homogeneous environment. The finding of several P. sylvestris/nigra type charcoal fragments in Hontalbilla suggests a very localised regional persistence of this taxon until the late Holocene at sites other than the relict populations of the River Cega and Navazo de los Valsaínes (Soriano et al., 2002).

Our data significantly extend the time period for the Holocene presence of $P$. pinaster in the Duero Basin in an extensive area of approximately $375 \mathrm{~km}^{2}$. The presence of the maritime pine in the Tierra de Pinares area since at least $6000 \mathrm{cal}$. yr BP constitutes definitive proof of its autochthony, which was previously suggested on the basis of palaeobotanical (Franco-Múgica et al., 2005; García-Antón et al., 2011; Hernández et al., 2011), historical (Calonge, 2003; Gil, 1991, 2008) and geobotanical data (Costa et al., 1997; Font Quer, 1954). The evidence contradicts the opinion expressed by several phytosociologists who assumed an artificial origin (Navarro and Valle, 1987) or a limited importance with respect to the 'potential natural vegetation' (Rivas Martínez, 1987) for these pine forests.

\section{Pinus pinaster: a 'versatile'species during the Iberian Holocene}

Maritime pine is currently the most widespread conifer on the Iberian Peninsula, where it grows in a great diversity of habitats and geographical areas (Alía et al., 1996; Costa et al., 1997). Its extensive natural distribution area was increased significantly by widespread afforestation during the 20th century (Alía et al., 1996). This is probably the main reason for the widespread opinion that exists discounting an important role of $P$. pinaster under 'natural' conditions (e.g. Peinado et al., 2008; Rivas Martínez, 1987), despite its dominance in several Iberian natural forest stands (Costa et al., 1997). Consequently, the only potential vegetation series presenting maritime pine forests as the most developed vegetation type (Valle, 2003) is restricted to areas with serpentine soils, which are characterised by poor productivity and toxicity for plants (Brady et al., 2005). However, the palaeobotanical record is helping to clarify the Holocene distribution of $P$. pinaster in Iberia, as well as its importance in Iberian forest ecosystems.

Anthracological investigations from central and northern Portugal have shown that the maritime pine has been widespread throughout the Holocene (Figueiral, 1995; Figueiral and Bettencourt, 2004; Tereso, 2009; Figure 6). There is evidence of a local presence even in the River Tagus estuary where García-Amorena et al. (2007) reported finding several $P$. pinaster stumps with an age of 7430-7930 cal. yr BP (García-Amorena et al., 2007; Figure 6). The anthracological studies suggest that this pine was present at many sites throughout Portugal and that it was an important species in the landscape, usually accompanied by other Mediterranean trees and shrubs (Figueiral, 1995). In this geographical framework, $P$. pinaster has demonstrated ecological plasticity, as there is Holocene evidence supporting its presence from the Atlantic shoreline to the mountains in the north, where its lower abundance could be due to the suitability of these areas for deciduous forests (Figueiral, 1995).

There are other sites in western Iberia where $P$. pinaster charcoal has been recovered, for instance from the Roman period at the foothills of the Teleno Mountains in NW Spain (Domergue and Herail, 1978) in an area with acidic and coarse-grained soils and a sub-Mediterranean climate. Farther south, Rubiales et al. (2009) identified $P$. pinaster charcoal in the Iron Age archaeological site of Castillejos II (c. 2200 cal. yr BP) at $550 \mathrm{~m}$ a.s.1. Charcoal from other plants, such as sclerophyllous Quercus and Cistus species, were also abundant. This site is especially interesting from a biogeographical point of view because of the presence of pines where natural pine is now extremely rare (Rubiales et al., 2009). There is also macrofossil evidence of $P$. pinaster in the eastern half of Iberia (Figure 6), including sites in the Supra-Mediterranean (Mora de Rubielos, 3200-3500 cal. yr BP; Richter and Eckstein, 1986), Meso-Mediterranean (Yecla, 730-570 cal. yr BP; Alcalde et al., 2004) and Thermo-Mediterranean belts (Santa Bárbara, Chalcolithic; Rodríguez-Ariza, 2000).

Several palynologists have distinguished a $P$. pinaster pollen type based on identification criteria provided by Roure (1985) and Carrión et al. (2000). Thus, the palynological record suggests 
that the maritime pine has played an important role in the Holocene landscapes of several areas of the Betic Ranges (Carrión, 2002; Carrión et al., 2001, 2003, 2004, 2007), in Navarrés, at the foothills of the Iberian Range (Carrión and van Geel, 1999), and on the southern slopes of the Gredos Mountains (López-Sáez et al., 2010). Most of these pollen sequences show that the expansions of the maritime pine are synchronous with those of several sclerophyllous trees and shrubs, particularly evergreen Quercus species (e.g. Carrión, 2002; Carrión and van Geel, 1999). In contrast, the sequence from the Gredos Mountains (López-Sáez et al., 2010) suggests a clear long-term dominance of $P$. pinaster, associated with an understorey rich in Mediterranean shrubs. In NW Iberia, several pollen sequences show a certain presence of $P$. pinaster type throughout the Holocene, but always discontinuously and in low percentages (e.g. Muñoz Sobrino et al., 2004; Ramil-Rego et al., 1998).

In summary, the Holocene fossil record on the Iberian Peninsula shows that the maritime pine has been present in very diverse habitats and geographical regions, including some areas where it is absent today. Palynological and anthracological records demonstrate that this pine has been commonly associated with Mediterranean trees and shrubs. The soil charcoal data from the sandy soils of Tierra de Pinares presented in this report provide novel and valuable information suggesting that maritime pine forests were present throughout the Holocene, thus notably spatially expanding its Holocene record. In addition, our data also suggest that Pinus pinaster formed pure stands under the limiting conditions of the Duero Basin (deep sandy soils and a continental Mediterranean climate). These findings complete the vegetation histories based on regional pollen sequences both spatially and taxonomically (Franco-Múgica et al., 2005; García-Antón et al., 2011), supporting the local presence of pines over wide areas and detailing the particular species that produced at least a portion of the pollen signal. There is a striking difference between the palynological record and the soil charcoal record of Tierra de Pinares. The soil charcoal only includes pines, whereas the pollen shows woody plants other than Pinus. These trees and shrubs could have been present in the understorey of the pine forest or growing on more favourable soils outside of the dune fields and sand sheets. Additionally, the difference between the records might have been caused by the different source areas of the pollen and soil charcoal studies.

\section{Conclusions}

Our soil charcoal data from palaeosols located in the Tierra de Pinares area (southern Duero Basin, central Spain) have provided firm evidence on the long-term presence and importance of $P$. pinaster in this extensive area covered with dune fields and sand sheets. Consequently, a natural origin of these inland Iberian pine forests is supported, and the hypothesis of an artificial origin for these forests linked to resin and wood exploitation has been proven unlikely. Moreover, our results provide further evidence of the persistence of widespread pine forests throughout the Holocene in these inland plateaux. The long-term persistence of these pine forests at a millennial scale constitutes an original vegetation history pattern for the inland areas of Iberia. The unsuitability of the sandy soils where these pine forests grow for human activities, such as crop cultivation and animal husbandry would have helped the maintenance of these forests until the present.

The pedoanthracological record described here greatly expands the known area of the Holocene presence of the maritime pine on the Iberian Peninsula. Increasing fossil evidence (pollen and macrofossils) suggests that this pine species has been widespread in Iberia during the last millennia. It would have covered areas with diverse climates and soils and coexisted with other Mediterranean trees and shrubs. We did not find any taxa other than pines in the Tierra de Pinares soil charcoal data set, possibly because of the continental Mediterranean climate and the deep sandy soils in this region, which are very limiting for the development of hardwood species.

\section{Acknowledgements}

We would like to express our gratitude to Nacho Cañas and Tomás Sánchez Pellicer (Agresta S. Cooperativa) for collecting some of the studied charcoal fragments and to Guillermo Calonge for drawing our attention to the palaeoecological significance of the Tierra de Pinares. César Morales thanks Silvia Guerrero for her steady support during this research. Pim van der Knaap and an anonymous reviewer are kindly acknowledged for their contributions to improve an earlier version of the manuscript.

\section{Funding}

C. Morales-Molino holds a Universidad Politécnica de Madrid pre-doctoral grant. This study was funded by the research projects CGL2008-06005 BOS - SensCom (Ministerio de Ciencia e Innovación, Spain) and 'Estudio de turberas en la Cuenca del Duero' (code 43711816057, Junta de Castilla y León, Spain).

\section{References}

Alcalde C, García-Amorena I, Gómez Manzaneque F et al. (2004) Nuevos datos de carbones y maderas fósiles de Pinus pinaster Aiton en el Holoceno de la Península Ibérica. Investigación Agraria: Sistemas y Recursos Forestales fuera de serie, 152-163.

Alía R, Martín Albertos S, De Miguel J et al. (1996) Las regiones de procedencia de Pinus pinaster Aiton. Madrid: Organismo Autónomo de Parques Nacionales.

Bateman MD and Díez-Herrero A (1999) Thermoluminiscence dates and palaeoenvironmental information of the late Quaternary sand deposits, Tierra de Pinares, Central Spain. Catena 34: 277-291.

Bernat M and Pérez-González A (2008) Inland aeolian deposits of the Iberian Peninsula: Sand dunes and clay dunes of the Duero Basin and the Manchega Plain. Palaeoclimatic considerations. Geomorphology 102: 207-220.

Brady KU, Kruckeberg AR and Bradshaw HD (2005) Evolutionary ecology of plant adaptation to serpentine soils. Annual Review of Ecology, Evolution and Systematics 36: 243-266

Calonge $\mathrm{G}$ (1987) El complejo ecológico y la organización de la explotación forestal en la Tierra de Pinares segoviana. Diputación Provincial de Segovia, Segovia.

Calonge G (1998) La Tierra de Pinares segoviana. Medio Ambiente en Castilla yLeón 5: 15-35.

Calonge $G$ (2003) Implicaciones biogeográficas de las ordenanzas medievales de las comunidades de Cuéllar y Sepúlveda sobre un monte de pinos como elemento esencial de la vegetación autóctona. Cuadernos SECF 16: 103-108.

Carcaillet C (1998) A spatially precise study of Holocene fire history, climate and human impact within the Maurienne valley, North French Alps. Journal of Ecology 86: 384-396.

Carcaillet C (2001) Are Holocene wood-charcoal fragments stratified in alpine and subalpine soils? Evidence from the Alps based on AMS ${ }^{14} \mathrm{C}$ dates. The Holocene 11: 231-242.

Carcaillet C (2007) Charred particle analysis. In: Elias SA (ed.) Encyclopedia of Quaternary Science. Amsterdam: Elsevier, 1582-1593.

Carcaillet C and Thinon M (1996) Pedoanthracological contribution to the study of the evolution of the upper treeline in the Maurienne Valley (North French Alps): Methodology and preliminary data. Review of Palaeobotany and Palynology 91: 399-416.

Carnelli AL, Theurillat J-P, Thinon M et al. (2004) Past uppermost tree limit in the Central European Alps (Switzerland) based on soil and soil charcoal. The Holocene 14: 393-405.

Carrión JS (2002) Patterns and processes of Late Quaternary environmental change in a mountain region of southwestern Europe. Quaternary Science Reviews 21 : 2047-2066.

Carrión JS and Leroy SAG (2010) Iberian floras through time: Land of diversity and survival. Review of Palaeobotany and Palynology 162:227-230.

Carrión JS and van Geel B (1999) Fine-resolution Upper Weichselian and Holocene palynological record from Navarrés (Valencia, Spain) and a discussion about factors of Mediterranean forest succession. Review of Palaeobotany and Palynology 106: 209-236. 
Carrión JS, Fernández S, González-Sampériz P et al. (2010) Expected trends and surprises in the Lateglacial and Holocene vegetation history of the Iberian Peninsula and Balearic Islands. Review of Palaeobotany and Palynology 162: 458-475.

Carrión JS, Fuentes N, González-Sampériz P et al. (2007) Holocene environmental change in a montane region of southern Europe with a long history of human settlement. Quaternary Science Reviews 26: 1455-1475.

Carrión JS, Munuera M, Dupré M et al. (2001) Abrupt vegetation changes in the Segura Mountains of southern Spain throughout the Holocene Journal of Ecology 89: 783-797.

Carrión JS, Navarro C, Navarro J et al. (2000) The distribution of cluster pine (Pinus pinaster) in Spain as derived from palaeoecological data: Relationships with phytosociological classification. The Holocene 10: 243-252.

Carrión JS, Sánchez-Gómez P, Mota JF et al. (2003) Holocene vegetation dynamics, fire and grazing in the Sierra de Gádor, southern Spain. The Holocene 13: 839-849.

Carrión JS, Yll EI, Willis KJ et al. (2004) Holocene forest history of the eastern plateau in the Segura Mountains (Murcia, southeastern Spain). Review of Palaeobotany and Palynology 132: 219-236.

Clark JS, Lynch J, Stocks BJ et al. (1998) Relationships between charcoal particles in air and sediments in west-central Siberia. The Holocene 8: 19-29.

Cortázar D (1891) Descripción fisica y geológica de la provincia de Segovia. Memoria de la Comisión del Mapa Geológico de España. Madrid: Ed. Imprenta y Fundición de Manuel Tello.

Costa Tenorio M, Morla C and Sainz Ollero H (eds) (1997) Los bosques ibéricos: Una interpretación geobotánica. Barcelona: Ed. Planeta.

De Lucas AI, González-Martínez SC, Hidalgo E et al. (2009) Admixture, one-source colonization or long-term persistence of maritime pine in the Castilian Plateau? Insights from nuclear microsatellite markers. Investigación Agraria: Sistemas y Recursos Forestales 18: 3-12.

Domergue C and Herail G (1978) Mines d'or romaines d'Espagne: le district de la Valduerna (León). Toulouse: Publications de l'Université de Toulouse-Le Mirail, Série B, Tome IV.

Dutoit T, Thinon M, Talon B et al. (2009) Sampling soil wood charcoals at a high spatial resolution: A new methodology to investigate the origin of grassland plant communities. Journal of Vegetation Science 20: 349-358.

Figueiral I (1995) Charcoal analysis and the history of Pinus pinaster (cluster pine) in Portugal. Review of Palaeobotany and Palynology 89: 441-454.

Figueiral I and Bettencourt AMS (2004) Middle/Late Bronze Age plant communities and their exploitation in the Cávado Basin (NW Portugal) as shown by charcoal analysis: The significance and co-occurrence of Quercus (deciduous)-Fabaceae. Vegetation History and Archaeobotany 13: 219-232.

Font Quer P (1954) La vegetación. In: Terán M (ed.) Geografia de España y Portugal vol. 2. Barcelona: Montaner y Simón, 145-271.

Franco Múgica F, García Antón M, Maldonado J et al. (2001) The Holocene history of Pinus forests in the Spanish Northern Meseta. The Holocene 11: 343-358.

Franco-Múgica F, García-Antón M, Maldonado-Ruiz J et al. (2005) Ancient pine forest on inland dunes in the Spanish northern meseta. Quaternary Research 63: 1-14.

García Álvarez S, Morla Juaristi C, Solana Gutiérrez J et al. (2009) Taxonomic differences between Pinus sylvestris and P. uncinata revealed in the stomata and cuticle characters for use in the study of fossil material. Review of Palaeobotany and Palynology 155: 61-68.

García-Amorena I, Gómez Manzaneque F, Rubiales JM et al. (2007) The Late Quaternary coastal forests of western Iberia: A study of their macroremains. Palaeogeography, Palaeoclimatology, Palaeoecology 254: 448-461.

García-Amorena I, Rubiales JM, Moreno Amat E et al. (2011) New macrofossil evidence of Pinus nigra Arnold on the Northern Iberian plateau during the Holocene. Review of Palaeobotany and Palynology 163: 281-288.

García Antón M, Franco Múgica F, Maldonado J et al. (1995) Una secuencia polínica en Quintana Redonda (Soria). Evolución holocena del tapiz vegetal en el Sistema Ibérico septentrional. Anales del Jardín Botánico de Madrid 52: 187-195.

García-Antón M, Franco-Múgica F, Morla-Juaristi C et al. (2011) The biogeographical role of Pinus forests on the Northern Spanish Meseta: A new Holocene sequence. Quaternary Science Reviews 30: 757-768.

García-Hidalgo JF, Temiño J and Segura M (2007) Holocene aeolian development in Central Spain; chronology, regional correlations and causal processes. Quaternary Science Reviews 26: 2661-2673.

Gil L (1991) Consideraciones históricas sobre Pinus pinaster Aiton en el paisaje vegetal de la península Ibérica. Estudios Geográficos 52: 5-27.

Gil L (2008) Pinares y rodenales: la diversidad que no se ve. Madrid: Real Academia de Ingeniería, $191 \mathrm{pp}$.
González-Sampériz P, Leroy SAG, Carrión JS et al. (2010) Steppes, savannahs, forests and phytodiversity reservoirs during the Pleistocene in the Iberian Peninsula. Review of Palaeobotany and Palynology 162: $427-457$.

Guerra JC, García de Celis AJ and Arroyo P (2006) Estructura y dinámica de una población de Betula alba L. en las llanuras sedimentarias de la cuenca del Duero (tramo medio del río Cega -Cuéllar, Segovia-). Serie geográfica Biogeografia: distribuciones, dinámicas y diversidad 13: 65-79.

Henry F, Talon B and Dutoit T (2010) The age and history of the French Mediterranean steppe revisited by soil wood charcoal analysis. The Holocene 20: 25-34.

Hernández L, Rubiales JM, Morales-Molino C et al. (2011) Reconstructing forest history from archaeological data: A case study in the Duero basin assessing the origin of controversial forests and the loss of tree populations of great biogeographical interest. Forest Ecology and Management 261: $1178-1187$

ICONA (1995) Segundo Inventario Forestal Nacional (1986-1995). Castilla y León: Segovia. Madrid: Ed. Ministerio de Agricultura Pesca y Alimentación.

Jacquiot C (1955) Atlas d'anatomie des bois des coniferes. Paris: Centre technique du bois.

López-García P, Arnanz AM, Macías R et al. (2003) Arqueobotánica de la Cueva de la Vaquera. In: Estremera MS (ed.) Primeros agricultores y ganaderos en la Meseta Norte: el Neolitico de la Cueva de la Vaquera (Torreiglesias, Segovia). Arqueología en Castilla y León vol. 11, Junta de Castilla y León, 247-256.

López-Sáez JA, López-Merino L, Alba-Sánchez F et al. (2010) Late Holocene ecological history of Pinus pinaster forests in the Sierra de Gredos of central Spain. Plant Ecology 206: 195-209.

Lynch JA, Clark JS and Stocks BJ (2004) Charcoal production, dispersal, and deposition from the Fort Providence experimental fire: Interpreting fire regimes from charcoal records in boreal forests. Canadian Journal of Forest Research 34: 1642-1656.

Muñoz Sobrino C, Ramil-Rego and Gómez-Orellana L (2004) Vegetation of the Lago de Sanabria area (NW Iberia) since the end of the Pleistocene: A palaeoecological reconstruction on the basis of two new pollen sequences. Vegetation History and Archaeobotany 13: 1-22.

Navarro F and Valle CJ (1987) Castilla y León. In: Peinado M and RivasMartínez S (eds) La vegetación de España. Madrid: Universidad de Alcalá de Henares, 117-162.

Peinado M, Monje L and Martínez Parras JM (2008) El paisaje vegetal de Castilla-La Mancha: manual de geobotánica. Toledo: Junta de Comunidades de Castilla-La Mancha, 610 pp.

Postigo-Mijarra JM, Morla C, Barrón E et al. (2010) Patterns of extinetion and persistence of Arctotertiary flora in Iberia during the Quaternary. Review of Palaeobotany and Palynology 162: 416-426.

Ramil-Rego P, Muñoz-Sobrino C, Rodríguez-Guitián MA et al. (1998) Differences in the vegetation of the North Iberian Peninsula during the last 16,000 years. Plant Ecology $138: 41-62$

Reimer PJ, Baillie MGL, Bard E et al. (2009) INTCAL09 and MARINE09 radiocarbon age calibration curves, $0-50,000$ years cal. BP. Radiocarbon 51: $1111-1150$

Richter D and Eckstein K (1986) Dendrocronología aplicada en la provincial de Teruel. Primer avance 1985-1986. Kalathos 5-6: 199-210.

Rivas-Martínez S (1987) Memoria del Mapa de Series de Vegetación de España. Madrid: ICONA, Ministerio de Agricultura, Pesca y Alimentación.

Rivas-Martínez S, Fernández-González F, Loidi J et al. (2001) Syntaxonomical checklist of vascular plant communities of Spain and Portugal to association level. Itinera Geobotanica 14: 5-341.

Rivas-Martínez S, Díaz TE, Fernández-González F et al. (2002) Vascular plant communities of Spain and Portugal. Addenda to the Syntaxonomical checklist of 2001. Itinera Geobotanica 15: 5-922.

Rodríguez-Ariza MO (2000) El paisaje vegetal en la Depresión de Vera durante la Prehistoria reciente. Una aproximación desde la Antracología. Trabajos de Prehistoria 57: 145-156.

Roig S, Gómez Manzaneque F, Masedo F et al. (1997) Estudio paleobotánico de estróbilos y maderas subfósiles holocenas en el yacimiento de Cevico Navero (Palencia, España). Anales del Jardín Botánico de Madrid 55: $111-123$

Roure JM (1985) Palinología Ibérica. Fam. 1 a 20. Cupressaceae a Betulaceae. Orsis 1: 43-49.

Rubiales JM, García-Amorena I, García Álvarez et al. (2009) Anthracological evidence suggests naturalness of Pinus pinaster in inland southwestern Iberia. Plant Ecology 200: 155-160.

Rubiales JM, Hernández L, Romero F et al. (2011) The use of forest resources in central Iberia during the Late Iron Age. Insights from the wood charcoal 
analysis of Pintia, a Vaccaean oppidum. Journal of Archaeological Science 38: 1-10.

Ruiz de la Torre J (1996) Mapa Forestal de España, hoja 5-5, Segovia. Madrid: Dirección General de Conservación de la Naturaleza, Ministerio de Medio Ambiente.

Schweingrüber FH (1990) Anatomy of European Woods. Stuttgart: Paul Haupt Bern and Stuttgart Publishers.

Soriano C, Gastón A, Bariego P et al. (2002) Catálogo florístico del barranco del río Cega (Segovia, España). Ecología 16: 153-220.

Stuiver M and Reimer PJ (1993) Extended 14C database and revised CALIB radiocarbon calibration program. Radiocarbon 35: 215-230. CALIB 6.0 radiocarbon calibration program is available online on: http://intcal.qub. ac.uk/calib/

Talon B (2010) Reconstruction of Holocene high-altitude vegetation cover in the French southern Alps: Evidence from soil charcoal. The Holocene 20: 35-44.

Tereso JP (2009) Plant macrofossils from the Roman settlement of Terronha de Pinhovelo, northwest Iberia. Vegetation History and Archaeobotany 18: 489-501.

Valle F (2003) Mapa de series de vegetación de Andalucía. Madrid: Ed. Rueda. Vernet JL, Ogererau P, Figueiral I et al. (2001) Guide d'identification des charbons de bois préhistoriques et récents du sud-ouest de l'Europe: France, Péninsule Ibérique et Iles Canaries. Paris: CNRS Editions. 